\title{
Introduction to Special Symposium: Beyond 'A Dangerous Method': Reclaiming Sabina Spielrein's Voice in the Field of Psychology and Religion
}

\author{
Pamela Cooper-White
}

Published online: 22 May 2014

(C) Springer Science+Business Media New York 2014

\section{Introduction}

Sabina Spielrein's name is now popularly best known, if at all, because of an American film released in 2011, A Dangerous Method (Cronenberg 2011), based on the eponymous book by historian John Kerr (1994) and sensationalized for Hollywood audiences. In planning for a presession of the Psychology, Culture and Religion Group (PCR) of the American Academy of Religion, the three of us represented in this symposium decided that it would be interesting and appropriate to focus a paper symposium on Spielrein's life and work. Our aim was to bring her authentic voice out of the considerable noise and hype surrounding the movie and the traumatic scandal it depicted in the early days of psychoanalysis. Why a symposium at a conference on psychology and religion? Early on in considering this topic, we had already discovered that Spielrein had a strong interest in religious and mythological themes, no doubt influenced by her formative interactions with C. G. Jung, and that she had developed an early version of the concept of a "death instinct" (Spielrein 1994) that for our discipline of psychology and religion carried interesting philosophical and cultural resonances. The release of the film was a timely catalyst.

\section{A glimpse into Spielrein's life and works}

The film itself focuses on just a few years of Spielrein's life, from her admission to the Burghölzli Hospital for treatment for "psychotic hysteria" by C. G. Jung to her graduation as a medical doctor and emigration from Zurich to Vienna and Freud's early circle of psychoanalysts. At the heart of this narrative is a trauma-Jung entered into a romantic and probably sexual relationship of some sort with Spielrein, which, as it began to come to light, threatened Jung's marriage and his reputation as a doctor. Freud became embroiled in the boundary violation as both Jung's wife Emma and Spielrein herself warned him that

Thanks go to Felicity Kelcourse for first proposing the idea for this symposium and to the Steering Committee of the Psychology, Culture and Religion Group for enthusiastically supporting it.

P. Cooper-White $(\bowtie)$

Columbia Theological Seminary, P.O. Box 520, Decatur, GA 30031, USA

e-mail: cooperwhitep@ctsnet.edu 
more was going on than Jung had vaguely implied in previous letters. Freud was alarmed that such a scandal would destroy not only Jung, his hoped-for "crown prince" of psychoanalysis, but could permanently tarnish the reputation of psychoanalysis itself. This worry prompted a series of technical papers by Freud that especially elucidate transference, countertransference, and the dynamics of the therapeutic relationship. In the aftermath, upon graduation with her medical degree, Spielrein emigrated to Vienna and joined Freud's own circle of analysts - at once declaring her independence from Jung, and establishing herself in the font of psychoanalysis as an original thinker and analyst in her own right.

This narrative is fairly well known in Jungian and some psychoanalytic circles, but is still largely unknown outside psychoanalysis. Spielrein is mostly viewed as a pawn in the increasingly hostile relations between Freud and Jung, and not much else. No doubt it is impossible to consider Spielrein without also addressing the influence of Freud and Jungand, as it will be seen in the paper here by Isabelle Noth-also Jean Piaget and other developmental psychologists. However, a closer examination of her writings shows that she was a prolific and creative analyst and writer in her own right, and her works are far from derivative. On the contrary, many of her writings propose ideas that were later credited to other, more acclaimed theorists. Her works therefore deserve a fuller exposition in English, in a style that is accessible to a wider audience than what is currently available. Her early life and works are described in the first paper in this symposium by Felicity Kelcourse (see also Kelcourse 2014).

\section{Sources: some recent recoveries}

Spielrein's story might have been forgotten altogether if it were not for the discovery of her diary from 1909 to 1912 as well as her correspondence with Jung and Freud, in the basement of the Palais Wilson in Geneva, Switzerland (formerly the Jean-Jacques Rousseau Institute of Psychology). Aldo Carotenuto's publication of these texts in Italian translation in 1980 was and remains the seminal source of information about Spielrein's thought, but, as evidenced by his book's title, A Secret Symmetry: Sabina Spielrein between Freud and Jung (Carotenuto 1980, 1982), his focus was not on Spielrein's own contributions to psychoanalysis, but on the triangle of relationships between Spielrein and the two warring founders of psychoanalysis and analytic psychology.

In 1982, Carotenuto's text was translated into English. The same year, another box of Spielrein documents was discovered in the family archive of the past director of the Rousseau Institute, and a revised version in German, which included previously unpublished letters from Jung to Spielrein, appeared in 1986 (Carotenuto 1986). After a significant gap in years, in 1994 historian John Kerr wrote his book A Most Dangerous Method (Kerr 1994) based largely on Carotenuto's sources, which brought Spielrein's story once again to light for English-language readers but again focused on the perils of early psychoanalysis as exemplified in the crisis of Spielrein's analysis with Jung and subsequent move to Vienna - and to Freud. Also in 1994, the very first translation into English of her significant paper "Destruction as a Cause of Coming into Being" (Spielrein 1994) was published in the Jungian Journal of Analytical Psychology.

Spielrein gained further visibility, mainly in German-speaking countries, through the film Ich hieß Sabina Spielrein (My Name Was Sabina Spielrein) directed in 2002 by Elisabeth Márton (Márton 2006). Unlike the more recent Hollywood film, this docudrama spans Spielrein's entire life and presents a compassionate portrait of a troubled but brilliant woman. Nevertheless, the film still tends to emphasize the drama of 
Spielrein's passionate longing for Jung and the turmoil of her early adult years. Around the same time, an edited volume (Covington and Wharton 2003) published English translations of the previously unpublished letters between Spielrein and Jung, along with perceptive essays on various aspects of Spielrein's life and thought. The volume, written by and for psychoanalytic writers, is quite specialized but offers important insights. A similar anthology, so far published only in German, presents six more essays on Spielrein's works. (Karger and Weismüller 2006). Her works began to be systematically edited and published in German in 1987 (Spielrein 2002, 2006) but are still mostly inaccessible in English and other languages.

\section{The return of the repressed?}

It has been suggested that Spielrein's full story was not only forgotten, but actively (though unconsciously) repressed as the figure who represented a trauma buried in the early history of psychoanalysis - her story was regarded as too "dangerous" to psychoanalysis itself as a theory and especially as a method and a profession. As many other traumatic stories related to the Holocaust are also still just surfacing now, even as we are observing the 75th anniversary of Kristallnacht in November 2013, her story as a Jewish woman analyst who through her theoretical writings passionately hoped to create a bridge between the Jewish and "Aryan" races is especially poignant (see Cooper-White's essay in this symposium). Sabina Spielrein stands as both an important and a tragic figure - exploited by Jung, often disregarded, misunderstood, or underestimated by her fellow analysts (including Freud), and finally murdered in her home village by the Nazis in 1942. Her life and works deserve a serious critical reclamation.

\section{References}

Carotenuto, A. (1980). Diario di una segreta simmetria: Sabina Spielrein tra Jung e Freud. Rome: Astrolabio.

Carotenuto, A. (1982). A secret symmetry: Sabina Spielrein between Freud and Jung. Pomerans, A., Shepley, J., Winston, K. (Trans.) New York: Pantheon.

Carotenuto, A. (1986). Tagebuch einer heimlichen Symmetrie: Sabina Spielrein zwischen Jung und Freud. Freiburg i. Br:: Kore.

Covington, C., \& Wharton, B. (Eds.). (2003). Sabina Spielrein: Forgotten pioneer of psychoanalysis. New York: Brunner-Routledge.

Cronenberg, D. (Director) (2011). A dangerous method (film). Los Angeles: Sony Pictures Classics.

Karger, A., \& Weismüller, C. (Eds.). (2006). Ich hieß Sabina Spielrein: Von einer, die auszog, Heilung zu suchen. Göttingen: Vandenhoeck \& Ruprecht.

Kelcourse, F. (2014). Spielrein, Sabina. In D. Leeming (Ed.), Encyclopedia of Psychology and Religion (pp. 1706-1710). New York: Springer.

Kerr, J. (1994). A most dangerous method: The story of Jung, Freud, and Sabina Spielrein. New York: Vintage.

Márton, E. (Director). (2006). My name was Sabina Spielrein (DVD). Chicago: Facets Video. (Orig. released as Ich hieß Sabina Spielrein, produced by Helgi Felix/Idé Film Felixson AB, 2002.) With brief interviews with Sabina Spielrein's family and friends, in Cine-Notes to My name was Sabina Spielrein (DVD) (pp. 10-11). Chicago: Facets Video.

Spielrein, S. (1994). Destruction as a cause of coming into being. Journal of Analytical Psychology, 39, $155-186$. http://www.arizonapsychoanalyticsociety.com/downloads/sabrina.pdf. Accessed 12 Feb. 2014.

Spielrein, S. (2002). Sabina Spielrein: Sämtliche Schriften, 2nd ed. Foreword by L. Lütkehaus. Hensch, T. (Ed.), Gießen: Psychosozial-Verlag/Edition Kore. (Orig. publ. 1987).

Spielrein, S. (2006). In T. Hensch (Ed.), “Nimm meine Seele”-Sabina Spielrein: Tagebücher und Schriften. Berlin: Edition Freitag. 